\title{
Metode Pengajaran dan Kurikulum Darus Sunnah Sebagai Institusi Hadis Bertaraf Internasional
}

\section{(Instructional Methods and Curriculum of Darus Sunnah as an International Hadith Institution)}

\section{Usep Dedi Rostandi, Ali Masrur, Rosihon Anwar}

Fakultas Ushuluddin UIN Sunan Gunung Djati Bandung, Indonesia usep.dedi@uinsgd.ac.id

DOI: $10.29240 /$ alquds.v4i2.1871

Submitted: 2019-06-30 | Revised: 2020-09-03 | Accepted: 2020-09-28

\begin{abstract}
This paper delves into "Darus Sunnah as an International Hadith Institution." This research was conducted to prove that Darus Sunnah is an Islamic boarding schoolexisting at the international level.This research also showed that the educational program of Darus Sunnah used four methods, namely: mudhäkarah, halaqah fajriyyah, munazhzhamah, and istijmäm.The learning method applied in Darus Sunnah wasstudent-centered, wherein students were required to discuss actively with the mudarris as facilitators. The methods used in this Islamic boarding school dailycomprised: bandongan, sorogan, tabfizh of hadith, tabfizh of Qur'an, and tabfiøh of yellow books. The students of Darus Sunnah were also directed to conduct a community service program (PPM) as an ideal of PPM model. This research proved that Darus Sunnah is an international hadith institution. This is proven by the following facts: 1. Darus Sunnah Islamic Boarding School has got a branch in Malaysia since 2012, located in al-Sakinah Eco Resort Kampung Janda Baik, Negeri Pahang, Malaysia. 2. Darus Sunnah Islamic Boarding School has sent $d_{\bar{a}}^{\prime} i$ to foreign countries, such as America and Malaysia. 3. The sending of students to Egypt is one proof that Darus Sunnah is an international boarding school. The program to send students to Egypt is in collaboration with the Lido Pesantren 4. Darus Sunnah Islamic boarding school also frequently receives international students especially students who study around Darus Sunnah Islamic boarding school.
\end{abstract}

Keywords: Darus Sunnah Islamic Boarding School; Methods; Curriculum, Hadith Institution

Abstrak. Tulisan ini mengkaji mengenai "Darus Sunnah sebagai Institusi Hadith Bertaraf Internasional" Penelitian ini dilakukan untuk membuktikan bahwa Darus Sunnah adalah pesantren hadis yang bertaraf internasional. Dengan menggunakan metode analisis deskriptif. Penelitian ini membuktikan bahwa model dan sistem pendidikan hadis yang diterapkan di Darus Sunnah adalah model Pesantren dan 
Madrasah. Penelitian ini juga menunjukkan bahwa Program pendidikan di Darus Sunnah menggunakan empat metode, yaitu: mudzakarah, halaqah fajriyyah, munazh zhamah, dan istijmam. Metode pembelajaran di Darus Sunnah adalah Pola Student Centre, santri dituntut aktif berdiskusi dengan para mudarris sebagai fasilitator. Adapun metode yang digunakan tiap hari adalah: bandongan, sorogan, tahfizh hadis, tahfizh Alqur'an, tahfizh kitab kuning. Adapun beberapa kitab dan mata kuliah yang dipelajari di Ponpes Darus Sunnah, didominasi oleh kajian-kajian kitab hadis dan ilmu hadis, walaupun terdapat matakuliah seperti tafsir, fiqih, dan bahasa. Penelitian ini juga telah membuktikan bahwa Darus Sunnah adalah sebuah institusi hadis bertaraf internasional. Ini dibuktikan dengan fakta-fakta di bawah ini:1. Ponpes Darus Sunnah memiliki cabang di Malaysia sejak tahun 2012, di al-Sakinah Eco Resort Kampung Janda-Baik Negeri Pahang, Malaysia 2. Ponpes Darus Sunnah telah mengirim da'i ke mancanegara, seperti Mesir, Amerika dan Malaysia. Pengiriman maha santri ke Mesir berkerjasama dengan Pesantren Lido, 4. Ponpes Darus Sunnah juga seringkali menerima maha santri dari mancanegara, khususnya mahasiswa yang kuliah di sekitar Ponpes Darus Sunnah.

Kata Kunci: Pesantren Darus Sunnah; Metode; Kurikulum; Institusi Hadis

\section{Pendahuluan}

Pesantren merupakan lembaga yang identik dengan agama Islam, melembaga di masyarakat, bersifat tradisional, dan akrab dengan geografis desa. Bahkan pesantren dinobatkan sebagai lembaga tertua di Indonesia, pesantren mengadopsi system boarding scool dan dikhususkan untuk memplejari sekaligus mendalami ilmu-ilmu ke-Islaman. Istilah pesantren juga dikenal dengan sebuatan bagi sebuah tempat, kamar, gubug, rumah kecil, bangunan yang sederhana, ruang tidur atau dalam Bahasa Arab dikenal "Fundũq", wisma, atau tempat tinggal yang tersusun dari bambu. ${ }^{1}$ Pesantren juga dijadikan sebagai lembaga pengembangan ajaran Islam dengan visi meneruskan warisan para nabi menyampaikan risallah Allah. ${ }^{2}$

Genealogi pesantren bermula dari tradisi Islam yakni tradisi tarekat. Sebab kaum sufi memiliki hubungan yang erat dengan pesantren. Tradisi tarekat merupakan tradisi awal ketika Islam masuk ke Nusantara. Kebiasaan yang ada

1 Abdullah Syukri Zarkasyi, Langkah Pengembangan Pesantren Dalam Rekontruksi Pendidikan Dan Tradisi Pesantren Religiusitas Iptek (Yogyakarta: Pustaka Pelajar, 1998); Abdullah Abdullah and Deden Mauli Darajat, "Peran Humas Pondok Modern Darusslam Gontor (PMDG) Dalam Membangun Lembaga Pendidikan," ETTIS AL: Journal of Communication 1, no. 2 (2016): 111-26. Hamid Fahmy Zarkasyi, "Imam Zarkasyi’s Modernization of Pesantren in Indonesia (A Case Study of Darussalam Gontor)," QIJIS (Qudus International Journal of Islamic Studies) 8, no. 1 (2020): 161-200.

${ }^{2}$ Zamakhsyari Dhofier, Tradisi Pesantren Studi Tentang Pandangan Hidup Kyai (Jakarta: LP3ES, 1994), 84. K M Akhiruddin, "Lembaga Pendidikan Islam Di Nusantara," TARBIYA: Jurnal Ilmu Pendidikan Islam 1, no. 1 (2015): 195-219. Erwin Mahrus, Zaenuddin Hudi Prasojo, and B Busro, "Messages of Religious Moderation Education in Sambas Islamic Manuscripts," Madania: Jurnal Kajian Keislaman 24, no. 1 (2020): 39-48. 
dalam tarekat seperti mengaji, berhalaqah, dan lainnya, atas dasar kebiasaan tersebut maka berkembang dan lahirlah istilah pesantren. Terdapat sejarah lain yang menyatakan bahwasanya pesantren merupakan istilah lembaga pendidikan agama Hindu-Buddha sebelum Islam masuk ke Nusantara, maka istilah tersebut diadopsi oleh agama Islam. ${ }^{3}$ Namun kendati seperti itu untuk menelisik lebih rigidnya mengenai genealogi pesantren, maka diperlukan penulusuran secara komprehensif mengenai masuknya Islam ke Nusantara.

Pesantren Ilmu Hadith Darus-Sunnah, Ciputat, telah didirikan oleh Prof. KH Ali Mustafa Ya'qub, Imam besar Masjid Istiqlal Jakarta, salah seorang ulama hadith di Asia Tenggara. Lokasinya beralamat di Jalan SD Inpres no. 11 Pisangan Barat Ciputat. Menurut KH. Ali Mustafa Yaqub, tujuan pendirian Darus Sunnah ini adalah: Pertama, karena kebanyakan umat Islam Indonesia tidak memahami persoalan-persoalan hadis dan ilmu hadis. Kedua, masih banyak ulama Indonesia yang kalau ditanya tentang sebuah hadis, ia tidak mampu memberi jawaban yang memuaskan kepada masyarakat Indonesia. Inilah alasan utama mengapa pesantren Ilmu Hadits Darus-sunnah yang berstatus perguruan tinggi itu didirikan pada tahun 1997. Seluruh maha santri yang mengikuti pelajaran di Darus-Sunnah terdiri dari mahasiswa yang sedang mengikui kuliah di berbagai perguruan tinggi di Jakarta. Selain menjalani kuliah di perguruan tinggi masing-masing, mereka mengikuti pengkajian hadis di Darus-Sunnah. Bahasa Arab menjadi bahasa pengantar di setiap kuliah dan seleksi untuk memasuki pesantren ini sangat ketat karena materi soal test seleksinya menggunakan bahasa Arab. ${ }^{4}$

Luas pesantren ini telah mencapai 1000 meter persegi, tetapi setiap tahun pihak pesantren hanya menerima 20 pelajar dari ratusan pemohon yang mendaftar tiap awal semester. Sampai saat ini, Darus-Sunnah telah meluluskan 67 sarjana ilmu hadis di Indonesia. Para alumni dianggap mampu membaca dan memahami kitab-kitab Shabih al-Bukhari, Shabih Muslim, Sunan Abu Dawud, Jami' al-Tirmidri dan Sunan al-Nasa'i. Namun, belakangan ini, pihak pesantren telah menerima banyak permintaan dan cadangan dari para ilmuan Islam Indonesia agar menambah lagi jumlah penerimaan para pelajar. Oleh karena itu, pihak pesantren berusaha meluaskan kawasannya. Tanah kosong berhampiran lokasi lama sudah dibeli dan akan segera dibangunkan asrama khusus untuk mahasiswa. $^{5}$

\footnotetext{
${ }^{3}$ Muhammad Rouf, "Memahami Tipologi Pesantren Dan Madrasah Sebagai Lembaga Pendidikan Islam Indonesia," TAD ARUS 5, no. 1 (2016): 68-92.

${ }^{4}$ Fauzi Deraman and Faisal Ahmad Shah, "Pengajian Hadith Di Nusantara: Indonesia, Selatan Thailand, Singapura" (Kuala Lumpur, n.d.).

${ }^{5}$ Ibid.
} 
Seperti diuraikan diatas bahwasanya pesantren merupakan Lembaga Pendidikan, pastinya memiliki metode pengajaran serta kurikulum yang memadai. Metode pengajaran merupakan suatu teknik, prosedur, urutan, langkah-langkah, tatacara, serta usaha yang ditempuh oleh pengajar demi tercapainya sebuah tujuan pembelajaran. ${ }^{6}$ Metode pembelajaran juga diartiskan sebagai pola yang memiliki karakteristik dalalm memaksimalkan prinsip dasar pendidikan supaya terjadinya proses pembelajaran yang ideal pada peserta didik. $^{7}$ Alhasil yang dimaksud dengan metode pembelajaran adalah teknik atau pola yang dilakukan oleh seorang guru guna menyampaikan materi pelajaran kepada peserta didik, supaya tersampikan dengan maksimal dan melahirkan pelajar yang ideal.

Selanjutnya kurikulum sebagai lembaga pendidikan pastinya memiliki kurikulum, baik itu kurikulum nasional atau lokal. Kurikulum adalah kumpulan sebuah proses yang diperuntunkan untuk peserta didik guna mendapatkan pengetahuan dan pemahaman yang utuh dan disesuaikan dengan lembaga pendidikan setempat. ${ }^{8}$ Kurikulum juga bertujuan untuk mengembangkan suatu keahlian dan mengarahkan apresiasi, sikap, dan nilai yang dibantu oleh lembaga atau sekolah. Juga dikatakan sebagai pengalaman pembelajaran yang diperoleh dari hasil pembelajaran baik itu di sekolah atau di suatu lembaga tertentu. ${ }^{9}$

Oleh karena itu, tulisan ini hendak mengeksplorasi beberapa masalah berikut: Pertama, seperti apa metode dan kurikulum pendidikan hadis yang diterapkan di Pesantren Ilmu Hadis, Darus Sunnah? Kedua, apakah pesantren hadis Darus Sunnah dapat dibuktikan sebagai lembaga pendidikan hadis yang bertaraf internasional?

Adapun pendekatan yang digunakan dalam penelitian ini adalah pendekatan kualitatif yang menggunakan metode deskriptif analisis serta kepustakaan (library research). Pengumpulan data menggunakan metode dokumentasi dan wawancara. Sedangkan teknik analisis data menggunakan model Seiddel dengan melalui beberapa proses tahapan, diantaranya mengidentifikasi hasil penelitian dilapangan, mengklarifikasi data, mensistensikan data, menganalisis data, dan mengkategorisasikan data. Adapun metode penentuan Subjek dan Objek penelitian. Subjek dalam penelitian ini dimana penulis dapat memperoleh data yang diperlukan. Subjek Penelitian ini

\footnotetext{
${ }^{6}$ Wina Sanjaya, Strategi Pembelajaran Berorientasi Standar Proses Pendidikan(Jakarta: Kencana Prenada Media Group, 2008),147

${ }^{7}$ Abdurrahman Ginting, Esensi Praktis Belajar dan Pembelajaran (Bandung: Humaniora, 2008), 42

8 Abdurrahman Ginting, Esensi Praktis Belajar dan Pembelajaran, 44

${ }_{9}^{9}$ Ali Mudlofir, Aplikasi Pengembangan Kurikulum Tingkat Satuan Pendidikan Dan Bahan Ajar Dalam Pendidikan Agama Islam, (Jakarta : PT Raja Grafindo Persada, Jakarta, 2012) $1-2$.
} 
adalah Pimpinan Darus Sunnah, Pengurus Pesantren Darus Sunnah, Pengajar Darus Sunnah, dan Santri Darus Sunnah. Sedangkan objek penelitian ini adalah Pondok Pesantren Darus Sunnah Ciputat, Tangerang, Banten.

Penelitian sebelumnya yang terkait dengan Pesantren Darus Sunnah belum banyak dilakukan. Ali Wafa' menyimpulkan bahwa Pesantren DarusSunnah adalah pesantren hadis pertama dan satu-satunya pesantren yang mempelajari hadis secara mendalam di Indonesia. ${ }^{10}$ Nastullah Nurdin menyatakan bahwa tidak mudah menemukan seorang mubaddis (ahli hadis) dalam arti terminologis seperti figur Kiai Ali Mustafa Yaqub. ${ }^{11}$ Syah Ul-Haq Abdul Fikri menyatakan, Ali Mustafa Yaqub dalam mengistinbatkan hukum Islam menggunakan dalil-dalil Alquran, hadis, ijma', qiyas, istihsan, maslahat mursalah, maqasidusy syariah, kaidah-kaidah ushuliyyah dan kaidah-kaidah fiqhiyah. $^{12}$

Riki Efendi telah menyimpulkan bahwa Ali Mustafa Yaqub dalam menyampaikan dakwahnya berpegang teguh kepada kode etik dakwah Nabi Saw. dan mempunyai karakteristik berdakwah seperti karakteristik Nabi Muhammad Saw. Metode Dakwah yang Efektif menurut Ali Mustafa Yaqub sangat kompleks dan dapat diterapkan pada masa sekarang ini. ${ }^{13}$ M. Husnul Mubarok menyimpulkan bahwa metode penentuan arah kiblat Ali Mustafa Yaqub adalah dengan cara mengetahui empat arah mata angin: Barat, Timur, Selatan, dan Utara yang menjadi arah terdekat menuju kakbah. Menurut Ali Mustafa, hasil ijtihadnya itu dapat memberi kemudahan kepada masyarakat muslim Indonesia, tanpa harus menghitung dengan carayang sangat menyulitkan umat Islam Indonesia. ${ }^{14}$

Ni'ma Diana Cholidah menyatakan bahwa Ali Mustafa lebih tertarik untuk memadukan antara tradisi lokal dan tradisi Arab. Oleh karena itu, Ali Mustafa menggagas konsep lokalisasi tradisi keIslaman. Ia juga menerapkan

${ }^{10}$ Ali Wafa', "Kiai Ali Mustafa Yaqub: Penggagas Kajian Hadis Di Indonesia," in 2nd Inhad International Murakarah \& Mu'tamar On Hadith, 2017.

${ }^{11}$ Nasrullah Nurdin, "Prof. Dr. KH. Ali Mustafa Yaqub, MA. Muhaddis Nusantara Bertaraf Internasional," in 2ND INHAD International Muzakarah \& Mu'tamar on Hadith, 2017.

${ }^{12}$ Syah Ul-Haq Abdul Fikri, "Pemikiran Huku Islam Prof. Dr. KH. Ali Mustafa Yaqub, M.A.” (Fakultas Syariah dan Hukum, UIN Syarif Hidayatullah, 2016).

${ }^{13}$ Riki Efendi, "Pemikiran Dan Aktifitas Dakwah Prof. Dr. KH. Ali Mustafa Yaqub, M.A.” (Fakultas Dakwah UIN Syarif Hidayatullah Jakarta, 2009).

${ }^{14}$ Muhammad Husnul Mubarok, "Pemikiran Ali Mustafa Yaqub Tentang Arah Kiblat" (UIN Sunan Kalijaga Yogyakarta, 2016). 
pendekatan kontekstual. Ali Mustafa termasuk tokoh kontemporer Indonesia yang mempertahankan kajian hadis dengan pendekatan kontekstual (ma'naw $).{ }^{15}$

\section{Kerangka Teori}

\section{Pondok Pesantren}

Karel A. Steenbrink menyatakan bahwa pendidikan pondok pesantren jika dilihat dari segi bentuk dan sistemnya berasal dari India dan dari masyarakat Hindu. Sebelum proses penyebaran Islam di Indonesia, sistem tersebut telah dipergunakan untuk pendidikan dan pengajaran agama Hindu di Jawa. Setelah Islam masuk dan banyak tersebar di Pulau Jawa, sistem tersebut kemudian diambil alih oleh Islam.

Pondok adalah asrama-asrama para santri yang disebut pondok atau tempat tinggal yang dibuat dari bambu. Sedangkan istilah Pesantren berasal dari kata santri, yang dengan awalan $P e$ di depan dan akhiran an berarti tempat tinggal para santri. Dalam lembaga pendidikan pesantren ada beberapa varian yang sangat penting sebagai lembaga pendidikan. Setidaknya ada lima (5) varian yang penting dan terikat dalam pondok peosantren. ${ }^{16}$

\section{Kyai dan Santri}

Menurut asal muasalnya, sebagaimana telah dirinci oleh Zamakhsyari Dhofier, perkataan atau istilah kyai dalam bahasa Jawa sering dipakai untuk tiga jenis gelar yang saling berbeda. Pertama, sebagai gelar kehormatan bagi barangbarang yang dianggap sakti dan kramat, misalnya kyai tombak pleret atau Kyai Garuda Kencana yang dipakai untuk sebutan kereta emas yang ada di kraton Yogyakarta. Kedua, sebagai gelar kehormatan bagi orang-orang tua pada umumnya. Ketiga, sebagai gelar yang diberikan oleh masyarakat kepada seseorang ahli agama Islam yang memiliki atau menjadi pimpinan pesantren. Santri adalah istilah lain dari murid atau siswa yang mencari ilmu pada lembaga pendidikan formal, bedanya santri ini mencari ilmu pada pondok pesantren. Di dunia pesantren istilah santri terbagi menjadi dua kategori.

\section{Pengajaran Kitab Kuning}

Kitab kuning adalah beberapa kitab klasik yang sering dikaji dan dipelajari oleh para santri dan kyai. Biasanya kertas-kertas pada kitab yang dikaji sudah lama usianya akan berubah menjadi kuning. Oleh karena itu, istilah kitab kuning ini muncul. Yang biasadikaji di pesantren adalah kitab-kitab klasik

\footnotetext{
${ }^{15}$ Ni'ma Diana Cholidah, "Kontribusi Ali Mustafa Yaqub Terhadap Kajian Hadis Kontemporer Di Indonesia” (Fakultas Ushuluddin UIN Syarif Hidayatullah Jakarta, 2011).

${ }^{16}$ Dhofier, Tradisi Pesantren Studi Tentang Pandangan Hidup Kyai.
} 
madzhab Syafi'i dalam bahasa arab tanpa disertai harakat, yang dinamakan kitab gundul.

Ada dua model dalam pengkajian kitab kuning. Pertama adalah sorogan, santri satu persatu secara bergantian membaca kitab tertentu dengan kyai secara langsung. Peran kyai dalam model ini sebatas hanya menyimak bacaan santri dengan disertai penjelasan. Di sini, peran santri harus aktif dalam proses pembelajaran. Kedua, bandongan. Di sini, peran kyai sangat aktif dalam proses pembelajaran. Kyai membaca salah satu kitab disertai dengan penjelasan dan sebagian besar santri ikut menerjemahkan kitab yang dibaca oleh kyai. ${ }^{17}$

\section{Madrasah}

Madrasah dalam peta dunia pendidikan di Indonesia bukansuatu lembaga yang indegenous (pribumi). Setidaknya hal ini dapat dilihat dari kata "madrasab" itu sendiri yang berasal dari bahasa Arab. Secara harfiah, kata ini berarti atau setara maknanya dengan kata Indonesia, yakni "sekolah". Madrasah mengandung arti tempat atau wahana anak mengenyam proses pembelajaran. Dengan demikian, secara teknis madsarah menggambarkan proses pembelajaran secara formal yang tidak berbeda dengan sekolah. Hanya dalam lingkup kultural, madarasah ini mempunyai konotasi spesifik. Yakni sebagai lembaga pendidikan yang dalam proses pembelajaran dan pendidikannya menitikberatkan pada persoalan agama.

Dalam catatan sejarah madrasah lahir dari lingkungan pondok pesantren, atau dengan kata lain madrasah adalah perluasan dan pengembangan pendidikan dari pondok pesantren yang mempunyai misi untuk mencerdaskan anak bangsa yang pada saat itu belum ada keinginan untuk tinggal atau menginap di pondok dalam proses belajarnya. Setidaknya hal ini dapat dilihat dari para pendiri awal lembaga pendidikan Madrasah yang sebagian besar didirikan oleh para Ulama yang menjadi pengasuh dan sekaligus pendiri Pondok Pesantren pada lembaganya masing-masing. Diawali oleh Syekh Amrullah Ahmad (1907) di Padang mendirikan Madrasah, KH Wahab Hasbullah bersama KH Mansyur (1914) dan KH. M. Hasyim Asy'ari yang pada tahun 1919 mendirikan Madrasah Salafiyah di Tebuireng Jombang.Instutisi ini lahir pada awal abad $20 \mathrm{M}$, yang saat itu dapat dianggap sebagai periode pertumbuhan madrasah dalam sejarah pendidikan Islam di Indonesia. ${ }^{18}$

\section{Sekolah}

${ }^{17}$ Ibid.

${ }^{18}$ Karel Steenbrink, Pesantren, Madrasah, Sekolah: Pendidikan Islam Dalam Kurun Modern (Jakarta: LP3ES, 1994). 
Di akhir abad 20, beberapa tokoh berfikir untuk mencari kemungkinan melibatkan pendidikan Islam dalam pengembangan pendidikan. Hal itu disebabkan karena pendidikan Islam tersebut dibiayai oleh rakyat sendiri, dan dengan demikian pendidikan umum akan dapat direalisasikan dengan biaya yang relatif lebih murah. Akan tetapi karena alasan politis, penggabungan sistem tersebut tidak terlaksana, sebagai akubat konsekwensi logis dari kebijaksanaan pemerintah kolonial Belanda yang tidak mau campur tangan dalam persoalan Islam. Kemudian pada tahun 1888 Menteri kolonial menolak memberikan subsidi kepada sekolah-sekolah Islam karena campur tangan Gubernur Jenderal yang tidak mau mengorbankan keuangan negara untuk sekolah-sekolah tersebut, yang pada akhirnya hanya berhasil mengembangkan suatu sistem pendidikan yang sebenarnya tidak menguntungkan pengaruh dan kewajiban (Belanda). Kemudian berdasarkan pertimbangan tersebut, didirikanlah apa yang disebut sekolah desa, sebuah lembaga pendidikan sederhana yang membuka jalan ke arah terwujudnya pendidikan umum, namum pada saat itu usulan untuk menggabungkan pendidikan Islam ditolak. ${ }^{19}$

Dengan menggunakan kerangka teori tentang sistem pendidikan Islam di Indonesia semacam di atas, kira-kira Pesantren Hadis Darus Sunnah itu termasuk kategori lembaga pendidikan Islam seperti apa? Pesantren, Madrasah atau sekolah? Atau Pesantren Darus Sunnah mencoba menggabungkan dua sistem pendidikan sekaligus: Pesantren dan sekolah?

\section{Riwayat Hidup Pendiri Pesantren Darus Sunnah: KH. Ali Mustafa Yaqub}

Prof. Dr. KH. Ali Mustafa Yaqub dilahirkan di desa Kemiri kecamatan Subah Kabupaten Batang Jawa Tengah pada 2 Maret 1952 dari pasangan Kiyai Yaqub dan Nyai Habibah. Ketika masih bayi dia telah diprediksi oleh seorang perempuan akan menjadi Kiyai besar di kemudian hari. Waktu itu, ia dibawa ibunya ke rumah budenya di Selatan Pekalongan di daerah pegunungan. Mereka berdua naik delman. Di sebelah ibunya duduk seorang wanira separuh baya yang selalu memandang wajah bayi yang tertidur di pangkuan ibunya ini.

Tak lama berselang si ibu berkata: "Mbak Yu lare niki mangke sampun ageng bade dados kiai (Anak ini kalau sudah besar akan menjadi kiai). Dengan nada setengah tidak percaya Nyai Siti Chabibah, Ibu Ali kecil menjawab: "Ah punopo inggih" (Ah Masak iya?). Wanita itu melanjutkan, "Mbak Yu titeni kemawon sak niki sampun ketingal tondo-tondonipun" (Mbak Yu perhatikan saja sekarang sudah kelihatan tanda-tandanya). Pada saatu itu, Ibu KH. Ali Musta, Hj. Siti Chabibah itu tidak mempedulikan omongan wanita tersebut sampai beberapa saat

${ }^{19}$ Ibid. 
sebelum meninggal pada 2007 baru ia menceritakan kisah tersebut setelah prediksi wanita tersebut menjadi kenyataan. ${ }^{20}$

Setelah menamatkan pendidikan Dasar, beliau meninggalkan kampung halamannya untuk pergi menuntut ilmu. Lalu pergi ke Jombang dan mondok di Pondok Seblak Jombang selama 3 tahun (1966-1969). Selanjutnya beliau pindah ke pondok Tebuireng di daerah yang sama pada 1969-1971. Beliau mempunyai hafalan yang sangat kuat, ketika nyantri di Tebu Ireng beliau hafal tidak kurang dari 10 kitab seperti Matn Jurumiyah, al-Baiquniah, Allfiah Ibnu Malik, al-Waraqat dan lain-lain.

Kemudian pada 1972 beliau masuk Universaitas Hasyim Asy'ari Jombang. Beliau kuliah di Fakultas Syari'ah sampai 1975. Pada 1976 beliau berangkat ke Saudi Arabia untuk melanjutkan kuliah di Fakultas Syariah Universitas Islam Muhammad bin Sa'ud I Riyadh, Saudi Arabia dalam bidang Tafsir Hadits dan lulus pada 1980. Program S2 beliau tempuh di Fakultas Pascasarjana Universitas King Saud di Riyadh, Saudi Arabia dalam bidang Tafsir Hadis dan lulus pada 1985. Belum cukup sampai di situ pada 2005 beliau pergi ke India untuk melanjutkan kuliah di S3 di Universitas Nizamia Hyderabad India dalam bidang hukum Islam dan mencapai gelar Doktor pada 2006. Sebelumnya pada 1998 beliau telah diangkat sebagai Guru Besar Hadis dan Ilmu Hadis di IIQ Jakarta. Gelar Doktor beliau peroleh setelah usia beliau 54 tahun. Beberapa tahun kemudian beliau menhembuskan napas terahir pada 28 April 2016. ${ }^{21}$

KH. Ali Mustafa Yaqub adalah seorang tokoh ulama yang banyak berkiprah di tengah masyarakat baik di dalam maupun di dalam negeri. Selain menjadi pengasuh pondok Darus-Sunnah beliau berkiprah di MUI pusat dimulai dari sebagai anggota Komisi Fatwa sampai menjadi wakil ketua Komis Fatwa dan wakil ketua Dewan Syari'ah, semua ini beliau jalani sampai 2010. Dalam bidang akademik beliau menjadi Guru Besar pada beberapa Perguruan Tinggi seperti IIQ Jakarta, pada program magister Fakultas Dirasat Islamiah UIN Syarif Hidayatullah Jakarta, dan Program Magister STAIN Pekalongan Jawa Tengah. Sementara di luar negeri beliau menjadi Penasihat Syari'ah Halal Transactions of Omaha Amerika Serikat, Advisor Darul Uloom, New York USA. Selain itu, beliau juga menjabat sebagai Rais Syuriah Pengurus Besar Nahdatul

20 Erwati Aziz, Darus-Sunnah International Institute for Hadith Sciences (Studi Tentang Kurikulum Dan Proses Pembelajaran) (Yogyakarta: Pustaka Pelajar, 2019), 46-48.

${ }^{21}$ Aziz, Darus-Sunnah International Institute for Hadith Sciences (Studi Tentang Kurikulum Dan Proses Pembelajaran). 
Ulama (PBNU) bidang Fatwa. Beliau pernah menjabat Na'ib Haji Indonesia, menjadi Ketua Umum Pimpinan Pusat Ikatan Imam Masjid.

\section{Sejarah dan Perkembangan Darus Sunnah}

Niatnya mendirikan pesantren Darus-Sunnah ini tidak lepas dari kepeduliannya terhadap hadis atau Sunah Nabi. Beliau mengatakan bahwa kajian hadis kurang mendapat perhatian dari umat Islam, padahal hadis merupakan sumber ajaran kedua setelah al-Qur'an. Hal inilah yang melatarbelakanginya mendirikan Pondok Darus-Sunnah yang memfokuskan kajiannya pada hadis dan ilmu hadis. Namun, bukan berarti bahwa di Pesantren Darus Sunnah tidak diajarkan ilmu lainnya. Selain Hadis dan ilmu Hadis, diajarkan pula ilmu Nahwu dan Sharaf dan berbagai ilmu yang menopang proses pembelajaran Hadis. ${ }^{22}$

Pembangunan gedung untuk Pesantren dimaksud pada masyarakat sekitar dan para jama'ah-jama'ah masjid di mana ia sering memberi ceramah. Beliau membuat brosur sederhana dengan menyebutkan dana yang sudah terkumpul sekaligus biaya pengeluarannya. Semua mahasantri dilibatkan untuk mencari dana dimaksud. Gedung itu digunakan untuk asrama sekaligus untuk tempat kuliah. Sampai pada saat itu mahasantri putri belum ada, baru menerima mahasantri putra. Penerimaan mahasantri putri baru dilaksanakan setelah gedung yang berada di seberang jalan selesai. Mahasantri putra pindah ke gedung baru sementara mahasantri putri menempati gedung yang lama sampai sekarang. ${ }^{23}$ Hal ini mungkin dimaksudkan Pak untuk memudahkan mengawasi dan menjaga serta membina mahasantri putri karena lokasinya menyatu dengan rumah yang beliau tempati. Setelah gedung selesai maka muncul masalah nama untuk Pondok, atau pesantren, pak kiai berembuk dengan beberapa orang mahasantri lama maka disetujuilah nama Pondok Pesantren Darus-Sunnah. Pak Ali Nurdin mengatakan bahwa beliaulah yang membuat logonya. ${ }^{24}$

Mengenai nama International Institute for Hadith Sciences, bermula dari kunjungan beberapa tokoh Malaysia ke Pesantren. Ketika mereka menyaksikan sistem pembelajaran dan materi yang diajarkan di pesantren ini mereka tertarik dan ingin mendirikan pesantren seperti ini di Malaysia. Setelah mereka menyatakan keinginan tersebut, Pak Kiai menyambut baik maka disepakatilah berdirinya Darus-Sunnah di Malaysia tepatnya di al-Sakinah Eco Resort Kampung Janda-baik Negeri Pahang sekitar $40 \mathrm{~km}$ dari Kuala Lumpur, berseberangan dengan kawasan wisata Genting Highland Malaysia. Menurut

\footnotetext{
22 Ibid.

${ }^{23}$ Zia al-Haramain (Direktur Darus-Sunnah) Wawancara oleh Asep Abdul Muhyi, Jakarta, Rabu 7 Agustus 2019.

${ }^{24}$ Ali Nurdin (Wakil Rektor III PTIQ), Wawancara oleh Asep Abdul Muhyi, Jakarta, Rabu 7 Agustus 2019.
} 
Pak Ali Nurdin mereka hanya menyiapkansarana dan prasarananya sementara dosen dan kuriku-lum semuanya adalah dari Pondok Darus-Sunnah Ciputat. ${ }^{25}$ Pada 2014 dua tahun sebelum Prof. Dr. Ali Yaqub wafat, ia telah mempersiapkan Darus-Sunnah agar tidak bergantung kepadanya, dengan membuka program santri kecil (reguler). ${ }^{26}$

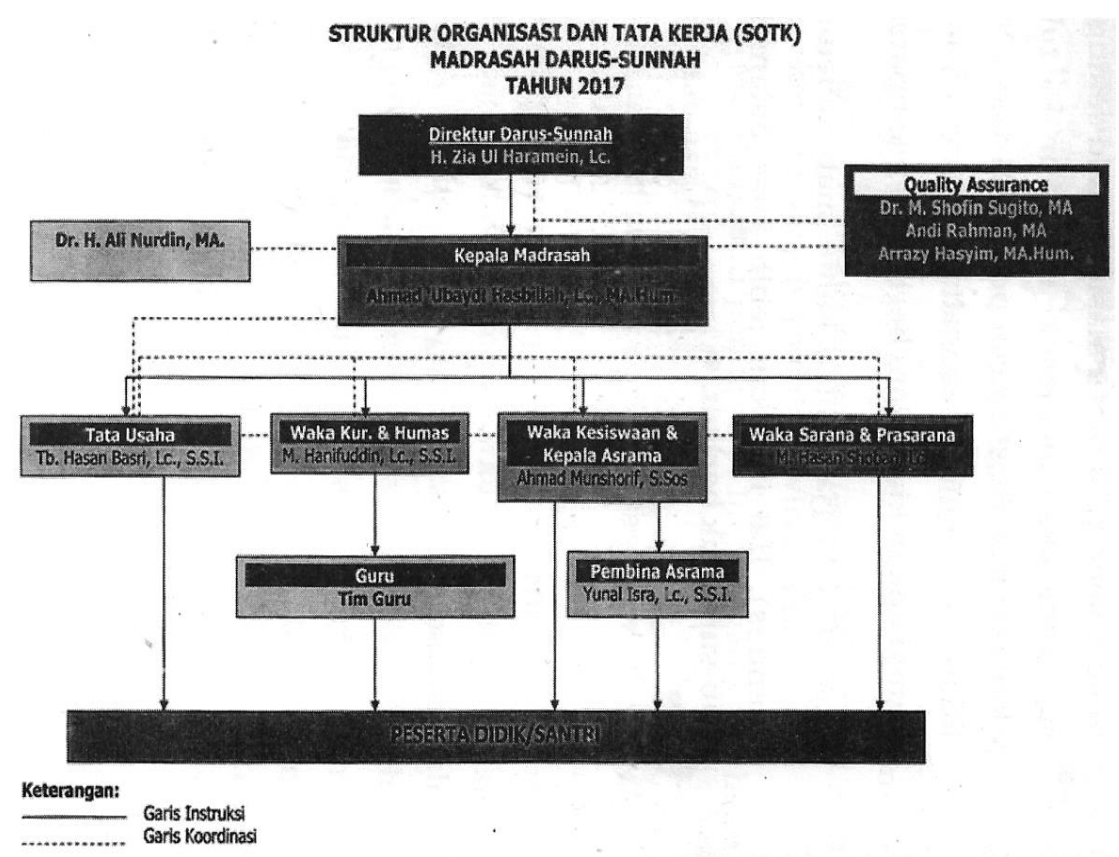

Gambar 1 Struktur Organisasi Madrasah Darus-Sunnah

Dalam gambar 1 terlihat bahwa Darus-Sunnah dipimpin oleh seorang Direktur yakni H. Zia Ul-Haramain Lc. putra kandung Prof. Dr. KH. AH Mustafa Yaqub. Di bawah direktur baru Kepala Madrasah yakni Ust. Ubaydi Hasbillah Lc, MA. Hum. di bawah Kepala Madrasah, ada 3 waka (wakil kepala) yaitu Waka Kur. \& Humas: M. Hanifuddin, Lc, SSI, waka Kesiswaan \& kepala Asrama: Ahmad Munshorif, S.Sos., dan Waka Sarana \& Prasarana: M. Hasan Shobari, Lc. dan bagian tata usaha: Tb. Hasan Basri, Lc, SSI. Tim guru berada di bawah waka Kur.dan Humas, sementara di bawah Waka Kesiswaan dan Kepala Asrama ada pembina asrama yakni Yunal Isra Lc, SSI. Sementara tingkat mahasantri tidak istilah pimpinan atau kepala tetapi yang ada hanya pengasuh.

${ }^{25}$ Ali Nurdin (Wakil Rektor III PTIQ), Wawancara oleh Asep Abdul Muhyi, Jakarta, Rabu 7 Agustus 2019.

${ }^{26}$ Ubaydi Hasbilah (Kepala Sekolah Madrasa), Wawancara oleh Asep Abdul Muhyi, Jakarta, Rabu 7 Agustus 2019. 
Ada 3 orang pengasuhnya yakni: Dr. M. Shofi'in Sugito, M.A., Andi Rahman, M.A., Arrazy Hasyim, MA. Hum. Sementara sejajar dengan kepala madrasah dan pengasuh mahasantri yang dihubungkan dengan garis adalah bapak Dr. AH Nurdin M.A., sebagai penasihat dan pengurus yayasan.pesantren hadis Darus Sunnah.

\section{Pembahasan}

\section{Metode Pendidikan Hadis Yang Diterapkan Di Pesantren Ilmu Hadis, Darus Sunnah}

Pesantren merupakan suatu lembaga pendidikan yang telah terbukti berperan penting dalam melakukan transmisi ilmu-ilmu keagamaan dimasyarakat.Teradapat beberapa pesantren yang menyesuaikan dengan tuntutan zaman kearah yang lebih modern dengan tidak meninggalkan doktrindoktrin klasik dan turas-turas ulama sebagai pembelajaran tradisi pesantren terkait dengan penanaman keagamaan Islam dan menumbuhkan ahlak yang baik dengan mengembangkan pendidikan yang variatif dan kompetitif.

Ponpes Darus Sunnah memiliki visi "Mengkader ulama sejak usia dini", dan memiliki Misi "Menyelenggarakan pendidikan agama yang syamil (holistic) berbasis al-Qur'an dan Hadis, kitab kuning, bahasa, sosial, seni dan budaya, sains dan teknologi, serta kewarganegaraan dan keterampilan. Oleh sebab itu, program pendidikan, metode pembelajaran, kurikulum, dan proses pembelajaran, semuanya berasakan pada visi dan misi ponpes Darus Sunnah.

Program merupakan bentuk atau rencana yang akan dilakukan, program juga dapat diartikan sebagai unit atau kesatuan kegiatan terrealisasi atau dapat diimplementasikan dari sebuah kebijakan, yang dilakukan oleh sekolompok orang yang terkumpul dalam sebuah organisasi tertentu. ${ }^{27}$ Program diartikan sebagai suatu unit atau kesatuan kegiatan yang dapat disebut sebagai sistem yang didalamnya terdapat rangkaian kegiatan yang dilakukan bukan hanya satu kali, tetapi berkesinambungan.

"Programs as the systematic application of resources guided by logic, beliefs, and assumptions identifying human needs and factors related to them. Defined completely, a program is: a set of planned systematic activities, using managed resources, to achieve specified goals, related to specific needs, of specific, identified, participating buman individuals or groups, in specific contexts, resulting in documentable outputs, outcomes, and impacts, following assumed (explicit or implicit) systems of beliefs (diagnostic,

27 Suharsimi Arikunto and Cepi Safruddin Abdul Jabar, Evaluasi Program Pendidikan:Pedoman Teoretis Praktis Bagi Mahasiswa Dan Praktisi Pendidikan (Jakarta: Bumi Aksara, 2009). 
causal, intervention, and implementation theories about how the program works, with specific, investigable costs and benefits". 28

Dari pemaparan diatas, dapat ditarik beberapa poin menegenai program, diantaranya: 1) Implementasi atau realisasi berupa kebijakan, 2) Terjadi dalam waktu relatif lama terjadi secara berkesinambungan sifatnya kegiatan jamak bukan tunggal, 3) Terjadi dalam organisasi yang melibatkan sekelompok orang. $^{29}$

Program pendidikan di Darus Sunnah terdapat pada tiga bagian yakni, Dirasah (study), Munazzhamah (organisasi), dan Istijmam (rekreasi).

\section{a. Dirasah (Pendidikan)}

Ponpes Darus Sunnah memiliki beberapa program pendidikan, salah satunya yakni pebelajaran. Demi tercapainya pembelajaran yang maksimal dan komprehensif, maka ponpes Darus Sunnah memiliki beberapa progam, diantaranya mudzakarah dan halaqoh, kedua program tersebut sudah dijalankan dari tahun ketahun, secara sistematis dan continue. ${ }^{30}$

1) Mudzakarah yakni kegiatan dilaksanakan ba'da shalat Isya, biasanya setiap santri disuruh berdiskusi mengenai mata pelajaran yang telah dan akan dipelajari.

2) Halaqah Fajriyyah yakni kegiatan belajar yang dilakukan ba'da shalat subuh, pada waktu ini para dewan pengajar memberikan penjelasan dan menambahkan terkait materi yang sudah mahasantri pelajari sebelumnya ketika Mudzakarah bersama Usrah masing- masing. ${ }^{31}$

3) Kelas Bilingual Pemahaman kelas bilingual dalam kamus bahasa Indonesia yakni siswa mampu atau biasa memakai dua bahasa secara aktif. Kedua bahasa tersebut dipakai sebagi media pembelajaran dan juga sebagai kemampuan dalam memahami sumber-sumber pelajaran, dengan tujuan untuk menstandarkan pengajaran tingkat internasional. Hal tersebut sesuai

${ }^{28}$ L. Kirkpatrick, Donald and James D. Kirkpatrick, Evaluating Training Programs: The Four Levels (San Francisco: Berrett-Koehler Publishers, 2006), 32.

${ }_{29}$ Syah Muhibbin, Psikologi Pendidikan Dengan Pendekatan Baru (Bandung: Remaja Rosdakarya, 2007).

${ }^{30}$ Zia al-Haramain, (Direktur Darus-Sunnah) Wawancara oleh Asep Abdul Muhyi, Jakarta, Rabu 7 Agustus 2019.

${ }^{31}$ U. N. Mahfudhon, Meniti Dakwab Di Jalan Sunnab. Biografi Kiai Ali Mustafa Yaqub (Jakarta: Yayasan Wakaf Darus-Sunnah, 2018), 177. 
dengan misi ponpes Darus Sunnah yakni International Institute for Hadist Sciences. $^{32}$

\section{b. Munazhzhamah}

Munazhzhamah merupakan kegiatan keorganisasian yang mempunyai peringkat kedua setelah Dirasah dalah hal apa yang harus diutamakan oleh mahasantri, salah satu pesan yang kerap kali disampaikan oleh K.H. Ali Mustafa Yaqub Selaku Khadim Ma'had Darus Sunnah sekaligus orang tua kami para Mahasantri adalah "Seorang yang mempunyai banyak ilmu dan tidak mempunyai pengetahuan dalam hal keorganisasian, maka dia akan mendapati kesulitan di dalam memanfaatkan dan menyebarkan ilmu yang dimilikinya”. Oleh karena itu, para santri Darus Sunnah diarahkan supaya mereka membuat atau bergabung dengan beberapa organisasi, demi mewujudkan pesan-pesan K.H. Ali Mustafa Yaqub. Darus Sunnah mempunyai beberapa lembaga yang memfasilitasi mahasantri dalam pengetahuan keorganisasian serta minat dan bakat, diantaranya:

IMDAR (Ikatan Mahasantri Darus-Sunnah), Lembaga Tahfizh Al Quran "Al Itqon" dan Panitia MUSTAHSAN, Lembaga Pers Mahasantri (LPM) NABAWI, Lembaga Kajian dan Riset RASIONALIKA, Sistem Informasi Darus Sunnah "SIDS", Panitia SPMB (Seleksi Penerimaan Mahasantri Baru), Panitia kursus bahasa Arab dan Inggris untuk anak-anak, Panitia SANRAM (Pesantren Ramadhan).

\section{c. Istijmam}

Istijmam atau istilah lainya study tour, yakni pembelajaran diluar kampus, dengan tujuan supaya santri bisa menyegarkan otak dan pikiran. Tidak hanya study tour ditambahkan dengan kegiatan lain seperti out bond, tadabbur alam, dan kegiatan lainya, yang berhubungan dengan kegiatan tersebut. Adapun pelaksanaanya dapat disesuaikan dengan jadwal yang telah ditentukan oleh pihak pondokpesantren dalam kalender akademik. Santri ponpes Darus Sunnah, tidak hanya sehat rohani, juga sehat jasmani. ${ }^{33}$

\section{Metode Pembelajaran}

Metode pembelajaran dapat diartikan cara atau pola yang khas dalam memanfaatkan berbagai prinsip dasar pendidikan serta berbagai teknik dan sumberdaya terkait lainnya agar terjadi proses pemblajaran pada diri

32 Aziz, Darus-Sunnah International Institute for Hadith Sciences (Studi Tentang Kurikulum Dan Proses Pembelajaran).

${ }_{33}$ Zia al-Haramain, (Direktur Darus-Sunnah) Wawancara oleh Asep Abdul Muhyi, Jakarta, Rabu 7 Agustus 2019. 
pembelajaran. ${ }^{34}$ Dengan kata lain metode pembelajaran adalah teknik penyajianyang dikuasai oleh seorang guru untuk menyajikan materi pelajaran kepada murid di dalam kelas baik secara individual atau secara kelompok agar materi pelajaran dapat diserap, dipahami dan dimanfaatkan oleh murid dengan baik. ${ }^{35}$ Dengan demikian metode dalam rangkaian sistem pembelajaran memegang peran yang sangat penting, karena keberhasilan pembelajaran sangat tergantung pada cara guru dalam menggunakan metode pembelajaran.

Terdapat beberapa metode pembelajaran yang dilakukan di Pesantren Darus Sunnah, diantaranya pembelajaran, penelitian dan pengabdian di masyarakat

\section{a. Pembelajaran}

Pembelajaran yang dilakukan di ponpes Darus Sunnah yakni menggunakan sistem klasikal dan non klasikal. Setiap santri mendapatkan binaan dan bimbingan dari para ustadz dan mudaris secara aktif dan progresif, hal tersbut bertujuan untuk menggali bakat para santri, baik bakat yang sifatya akademik dan bakat non akademik. Tutor sebaya, dilaksanakan oleh para santri, kegiatan pembelajaran yang dilaksanakan oleh satu orang santri kepada seorang santri lainya. Tutor sebaya biasanya dilakukan ketika pembelajaran yang sifatnya hafala, santri yang telah menyetor hafalanya biasanya akan menjadi tutor bagi santri yang belum setor hapalan.

Pola pengajaran yang dilakukan di ponpes Darus Sunnah yakni pola Student Centre, santri dituntut aktif berdiskusi dengan para mudaris sebagai fasilitator. Pola Student Centre memiliki kelebihan dimana santri lebih kreatif berinovasi. Hal tesrbut juga mendorong kepada para mudaris untuk selalu mengembangkan dan menyesuaikan materi pengaiian yang terdapat di ponpes Darus Sunnah. Adapun metode yang digunakan tiap hari yakni: Bandongan, Sorogan, Tahfizh Hadis, Tahfizh Qur'an dan Tahfizh Kitab Kuning. ${ }^{36}$

\section{d. Penelitian}

Maha santri Ponpes Darus Sunnah di wajibkan melakukan penelitian untuk mendapatkan ijazah dan gelar dari Ponpes Darus Sunnah, meskipun belum secara resmi ijazahnya diakui oleh Negara. Penelitian tersebut berbentuk

\footnotetext{
34 Abdurrahman Ginting, Esensi Praktis Belajar Dan Pembelajaran (Bandung: Humaniora, 2008).

35 Abu Ahmadi and Joko Tri Prastya, Strategi Belajar Mengajar (Bandung: CV Pustaka Setia, 2005), 52.

${ }^{36}$ Mahfudhon, Meniti Dakwah Di Jalan Sunnah. Biografi Kiai Ali Mustafa Yaqub.
} 
skripsi dengan focus kajian takhrij hadis, penulisan penelitian disesuaikan dengan kaidah-kaidah ilmiah yang berlaku. Skripsi maha santri Ponpes Darus Sunnah nantinya diujiankan sebagiman ujian skripsi di kampus. Skripsi maha santri sejauh ini masih menggunakan bahasa Indonesia, walaupun ada beberapa yang menggunakan bahasa Arab dan Inggris.

\section{e. Program Pengabdian Masyarakat (PPM)}

Program pengabdian masyarakat (PPM) biasanya dilakukan oleh maha santri Ponpes Darus Sunnah tingkat akhir. Pengabdian masyarakat atau PPM di Ponpes Darus Sunnah suadah berjalan lama, hal tersbut dilakukan untuk meningkatkan kemapuan maha santri dalam berdakwah di masyarakat.

Program pengabdian masyarakat (PPM) yang dilakukan oleh maha santri Ponpes Darus Sunnah bisa menjadi model PPM yang ideal, sebab PPM yang dilakukan oleh maha santri jarang dilakukan oleh yang lainya. Salah satu program PPM Ponpes Darus Sunnah yakni mengirimkan maha santri untuk berdakwah di Papua, di Malaysia, bahkan di Amerika. Sebelum melakukan PPM maha santri dibekali dengan berbagai keahlian seperti aktif berbahasa asing Arab dan Inggris. Maha santri dituntut untuk menyebarkan Islam yang rhamtan lil'alamin, berdakwah, mengajarkan baca tulis al-Qur'an, dan mengenalkan beberapa kajian hadis, baik dari segi ilmu musthalal hadis atau yang lainya. Untuk PPM ke daerah-daerah yang ada di Indonesia, masih berjalan sebagaiman biasanya, seperti pengiriman maha santri ke Papua Barat, Pakpak, Raja Ampat, adapun program bulam Ramadhan, untuk pengiriman dai ke Papua untuk sementara waktu diberhentikan terlebih dahulu. ${ }^{37}$

\section{Kurikulum Pendidikan Hadis Yang Diterapkan Di Pesantren IImu Hadis, Darus Sunnah}

Kurikulum pesantren adalah muatan proses, baik formal maupun informal yang diperuntukkan bagi peliajar untuk memperoleh pengetahuan dan pemahaman, mengembangkan keahlian dan mengubah apresiasi sikap dan nilai dengan bantuan pesantren". Sedangkan Maurice Dulton mengatakan "Kurikulum dipahami sebagai pengalaman-pengalaman yang didapatkan oleh pembelajar di bawah naungan lembaga pendidikan. ${ }^{38}$

Kurikulum sebagai sebuah program/rencana pembelajaran, tidaklah hanya berisi tentang program kegiatan, tetapi juga berisi tentang tujuan yang harus ditempuh beserta alat evaluasi untuk mengetahui keberhasilan pencapaian

\footnotetext{
${ }^{37}$ Zia al-Haramain, (Direktur Darus-Sunnah) Wawancara oleh Asep Abdul Muhyi, Jakarta, 25 Oktober 2019.

38 Ali Mudlofir, Aplikasi Pengembangan Kurikulum Tingkat Satuan Pendidikan Dan Baban Ajar Dalam Pendidikan Agama Islam (Jakarta: PT Raja Grafindo Persada, 2012), 1-2.
} 
tujuan, disamping itu juga berisi tentang alat atau media yang diharapkan mampu menunjang pencapaian tujuan tersebut. Kurikulum sebagai suatu rencana disusun untuk melancarkan proses belajar mengajar dibawah bimbingan dan tanggung jawab lembaga pendidikan beserta staf pengajarnya. ${ }^{39}$

Jadi kurikulum adalah suatu program pendidikan yang berisikan berbagai bahan ajar dan pengalaman belajar yang diprogramkan, direncanakan dan dirancangkan secara sistemik atas dasar norma-norma yang berlaku yang dijadikan pedoman dalam proses pembelajaran bagi tenaga kependidikan dan peserta didik untuk mencapai tujuan pendidikan. ${ }^{40}$

Pengembangan kurikulum merupakan proses perencanaan kurikulum secara sitematis dan kontinyu, supaya membentuk kurikulum yang luas dan spesifik. Proses kurikulum berhubungan dengan seleksi dan pengorganisasian. Adapun komponen yang mendukung terbentuknya kurikulum dianataranya, menetapkan jadwal pengorganisasian kurikulum dan spesifikasi tujuan yang disarankan, mata pelajaran, kegiatan mengacu pada kreasi sumber-sumber unit, rencana unit, dan garis pelajaran kurikulum ganda lainnya, suapaya proses pembelajaran berjalan dengan lancer dan baik. ${ }^{41}$

1.42

Secara ringkas, kurikulum ponpes Darus Sunnah termaktub dalam tabel

\begin{tabular}{|l|l|l|l|}
\hline Mata Pelajaran & Materi Ajar & $\begin{array}{l}\text { Program } \\
\text { Unggulan }\end{array}$ & Nilai Dasar Karakter \\
\hline $\begin{array}{l}\text { Pendidikan agama } \\
\text { berbasis al-Qur'an }\end{array}$ & $\begin{array}{l}\text { Tajwid, tahsin, } \\
\text { tahfidz, tafsir, ulumul } \\
\text { Qur'an, ulumul tafsir, } \\
\text { nagham }\end{array}$ & $\begin{array}{l}\text { LTTQH (tahsin } \\
\text { al-Qur'an intensif, } \\
\text { tahfidz murni, } \\
\text { tahfidz terbatas, } \\
\text { tahfidz hadis one } \\
\text { day one hadith } \\
\text { five ayats }\end{array}$ & Kokoh dalam prinsip \\
\hline Pendidikan agama & Hadis, ilmu hadis & Bandongan, & Tegas dalam bersikap \\
\hline
\end{tabular}

${ }^{39}$ Mudlofir, Aplikasi Pengembangan Kurikulum Tingkat Satuan Pendidikan Dan Bahan Ajar Dalam Pendidikan Agama Islam.

${ }^{40}$ Dakir, Perencanaan Dan Pengembangan Kurikulum (Jakarta: PT. Rineka Cipta, 2004), 3.

41 Oemar Hamalik, Dasar-Dasar Pengembangan Kurikulum (Bandung: PT Remaja Rosdakarya, 2007), 183-84.

${ }^{42}$ Tim Penyusun, Pedoman Akademik Madrasah Darus Sunnah Eanam Tabun Setingkat Tsanawiyah Aliyah, 2014-2020 (Jakarta: Darus Sunnah, 2014); Mahfudhon, Meniti Dakwah Di Jalan Sunnah. Biografi Kiai Ali Mustafa Yaqub. 


\begin{tabular}{|c|c|c|c|}
\hline $\begin{array}{l}\text { berbasis hadis dan } \\
\text { kitab kuning }\end{array}$ & $\begin{array}{l}\text { (tahfidz } \\
\text { musthalal hadis, } \\
\text { takhrij, dan fahmul } \\
\text { hadis), fiqih (fiqih } \\
\text { madzhab, fiqih } \\
\text { muqaran, ushul fiqih, } \\
\text { dan qawaid fiqih), } \\
\text { aqidah ahlus sunnah } \\
\text { wal jama'ah, akhlak, } \\
\text { sirah nabawiyah, } \\
\text { tarikh Islam. }\end{array}$ & $\begin{array}{l}\text { sorogan, tahfidz } \\
\text { kitab kuning }\end{array}$ & \\
\hline $\begin{array}{l}\text { Pendidikan agama } \\
\text { berbasis } \\
\text { bahasa dan budaya. }\end{array}$ & $\begin{array}{l}\text { Ilmu bahasa Arab } \\
\text { (nahwu, sharaf, } \\
\text { balagah), ilmu bahasa } \\
\text { Inggris, bahasa } \\
\text { Indonesia, sastra } \\
\text { Indonesia, ilmu seni, } \\
\text { ilmu budaya, ilmu } \\
\text { dakwah. }\end{array}$ & $\begin{array}{l}\text { Praktikum nahwu, } \\
\text { praktikum sharaf, } \\
\text { praktikum } \\
\text { dakwah, living } \\
\text { hadis }\end{array}$ & $\begin{array}{l}\text { Luwes dalam } \\
\text { penampilan }\end{array}$ \\
\hline $\begin{array}{l}\text { Pendidikan agama } \\
\text { berbasis ilmu sosial } \\
\text { dan sains }\end{array}$ & $\begin{array}{lr}\text { Ilmu pengetahuan } \\
\text { sosial, } \\
\text { pengetahuan alam, } \\
\text { matematika (standar } \\
\text { nasional Indonesia) }\end{array}$ & $\begin{array}{l}\text { Lembaga sains } \\
\text { Islam praktis (el- } \\
\text { SIP) dengan } \\
\text { program } \\
\text { bimbingan OSN }\end{array}$ & $\begin{array}{l}\text { Luwes dalam } \\
\text { penampilan }\end{array}$ \\
\hline $\begin{array}{l}\text { Pendidikan agama } \\
\text { berbasis } \\
\text { kewarganegaraan } \\
\text { dan keterampilan }\end{array}$ & $\begin{array}{l}\text { Pendidikan } \\
\text { kewarganegaraan dan } \\
\text { keIndonesian, } \\
\text { kepramukaan, olah } \\
\text { raga, kesehatan, } \\
\text { keterampilan bahasa } \\
\text { Arab dan Inggris } \\
\text { aktif (lisan dan } \\
\text { tulisan), bimbingan } \\
\text { karya ilmiah, } \\
\text { keterampilan } \\
\text { keagamaan praktis }\end{array}$ & $\begin{array}{l}\text { Program } \\
\text { pengabdian } \\
\text { masyarakat (PPM), } \\
\text { bahasa Arab dan } \\
\text { bahasa Inggris } \\
\text { aktif (lisan dan } \\
\text { tulisan), program } \\
\text { santri berkarya, } \\
\text { one class one } \\
\text { book, program } \\
\text { one class more } \\
\text { than one book, } \\
\text { dan one man one } \\
\text { book }\end{array}$ & $\begin{array}{ll}\text { Luwes dalam } \\
\text { penampilan }\end{array}$ \\
\hline
\end{tabular}

Adapun kegiatan kurikulum di antaranya: Tahsin dan Tahfizh al-Qur'an, Pembinaan Bahasa asing yakni bahasa Inggris dan bahasa Arab, Mudzakarah 
yang dilakukan setelah melaksanakan shalat Isya, Tasmi' al-Qur'an Jum'at, Puasa sunnah, baik hari Senin dan Kamis, atau puasa sunnah yang lainya, Qiyamul lail, rutin dilaksanakan setiap mau shalat Subuh, Jamaah shalat wajib lima waktu, Istighasah dilakukan setaip haris jum'at setelah shalat subuh, Tahlil setiap sudah shlat magrib dan malam jum'at, Muhadarah dan pembacaan barjanzi atau maulid Nabi, Diskusi dan musyawarah santri. ${ }^{43}$

\section{Keunggulan Kurikukulum}

a. Integrated Curriculum (pendidikan terintegrasi)

Pembelajaran diberikan secara holistic, berkaitan, berkesinambungan, di Madrasah, di Sekolah dan di Pesantren (asrama). Pembelajaran di pesantren dan sekolah sangat berkaitan, dan saling melengkapi satu sama lain. Ketika disekolah santri diberikan pembelajaran yang sifatnya umum (sains), sedangkan di pesantren santri dibekali dengan keilmuan agama yang mumpuni. Hal itu diharapkan agar seorang santri mampu mengintegritaskan antar ilmu umum (sains) dengan ilmu agama. Santri Darus Sunnah dibekali dengan pengetahun hadis yang memupuni, dan juga memiliki kemahiran berbahasa asing, maka mereka diperuntutkan bagaimana cara mengamalkan hadis dengan berbagai pendekatan keilmuan (sains), mahas santri Darus Sunnah berusaha menginterkoneksikan antara hadis dan sains.

b. Habitual Curriculum (pembiasaan nilai-nilai)

Materi ajar bersifat teoritik dan praktik untuk kemudian dibiasakan mengamalkan ajaran Islam dalam kehidupan sehari-hari melalui program ibya' alSunnah (living sunnah). KH Mustafa Ali Yaqub memiliki metode pemahan hadis yang cukup menarik, ia memahami hadis memakai strategi skala perioritas dalam ibadah. Sedangkan sebelumnya ia menggunakan metode ijmali yakni metode menjelaskan pemaknaan hadis yang bersifat global, secara tekstual dan parsial (separuh-separuh), hadis tersebut tidak dipahami utuh, kontekstual dan komprehensif, sehingga pemahamanya menjadi kurang akurat. ${ }^{44}$

c. Active Learning (partisipatif, kolaboratif, sorogan)

Santri secara aktif dilibatkan dalam proses pembelajaran dan penanaman nilai. Ponpes Darus Sunnah membiasakan maha santrinya untuk berpartisipasi

${ }^{43}$ Tim Penyusun, Pedoman Akademik Madrasah Darus Sunnah Eanam Tabun Setingkat Tsanawiyah Aliyah, 2014-2020.

${ }^{44}$ Ali Mustafa Yaqub and Nurul Huda Maarif, Haji Pengabdi Setan (Jakarta: Pustaka Firdaus, 2006), 147. 
dalam melaksanakan dan mewujudkan visi dan misi Ponpes Darus Sunnah. Pembelajaran di Ponpes Darus Sunnah salah satunya menggunakan metode sorogan. Metode sorogan merupakan metode pembelajaran tradisional juga dijadikan sebagai metode yang ideal dalam mempelajari bahasa Arab, hal tersebut bisa mempermudah dalam memahami kitab kuning. ${ }^{45}$

d. Multi Intellegences

Menumbuhkan seluruh potensi dan keserdasan santri secara aktif. Untuk masalaj kecerdasan, bahwa Ponpes Darus Sunnah menyaring beberapa santri yang mumpuni untuk diterima di Ponpes Darus Sunnah. Seleksi masuk Ponpes Darus Sunnah dilaksanakan dengan ketat, adapun materi yang diujiankan seperti bahasa Arab, Fiqih dan lainya. Sehingga hal tersbut menjadi modal dasar untuk mengembangkan kecerdasan seorang santri.

e. Life Skill and Vocational Skill

Santri dibekali keterampilan dan keahlian yang kompetitif. Program PPM merupakan salah satu program untuk meningkatkan keterampilan dan keahlian maha santri dalam mengamalkan ilmunya ditengah masyarakat. PPM sudah berjalan sejak lama di Ponpes Darus Sunnah, sangat besar sekali manfaat dilaksanakannya PPM untuk maha santri. Semakin sering melakukan PPM maka semakin terampil dalam mengembangkan keahlian. ${ }^{46}$

\section{Ponpes Darus Sunnah Sebagai Lembaga Pendidikan Hadis Yang Bertaraf Internasional}

Di bagian ini akan ditunjukan beberapa indikasi atau bukti bahwa Ponpes Darus Sunnah telah melakukan banyak hal yang menunjukan bahwa Ponpes Darus Sunnah telah memenuhi sebuah Lembaga yang bertarap internasional. Indikasi tersebut diantaranya:

a. Memiliki Cabang di Luar Negeri

Ponpes Darus Sunnah, sudah menjadi pondok pesantren Internasional, diantaranya memiliki cabang di Malaysia pada tahun 2012, terletak di al-Sakinah Eco Resort Kampung Janda-Baik Negeri Pahang, Malaysia. Ponpes Darus Sunnah mempunyai program mengirimkan da'i ke mancan Negara seperti

20.

${ }^{45}$ Syamsudin Asrafi, Metodologi Pembelajaran Bahasa Arab (Yogyakarta: Idea Press, 2010),

${ }^{46}$ Tim Penyusun, Pedoman Akademik Madrasah Darus Sunnab Eanam Tabun Setingkat Tsanawiyah Aliyah, 2014-2020. 
Malaysia dan Inggris, dengan pembekalan bahas Inggris dan Arab yang mumpuni, maka maha santri bisa berdakwah di kancah internasional. ${ }^{47}$

Darus Sunnah di Malaysia, belum bisa mendirikan lembaga atau yayasan khusus seperti halnya di Indonesia, sebab terkendala dengan perizinan yang cukup ketat dan rumit. Pendirian lembaga pe ndidikan di Malaysia harus mengikuti aturan yang telah di sahkan oleh Pemerintah Malaysia, seperti muatan kurikulum pendidikan di yayasan yang berdomisili di Malaysia, harus sesuai dengan kurikulum yang ditetapkan oleh Pemerintah Malaysia, hal ini menjadi kendala untuk Darus Sunnah mendirikan yayasan secara permanen di Malaysia.

Hambatan yang kedua yakni tempat yang jauh dari universitas. Lokasi Darus Sunnah di Malaysia merupakan tanah wakaf dari warga Malaysia. Lokasi yang jauh dari universitas menjadi kendala untuk para santri menginap tiap hari di lokasi Darus Sunnah, sehingga mereka mengadakan sisitem daurah, dengan ketentuan-ketentuan yang telah disepakati oleh pihak Darus Sunnah dan santri. Daurah dilakukan setiap satu minggu sekali pada hari libur yakni Sabtu dan Minggu, para maha santri mengaji di Darus Sunnah dengan Ust Syamsul, dia merupakan ustadz yang dikirim langsung dari Darus Sunnah Ciputat, Baten. Ust Syamsul tersebut diutus langsung oleh pimpinan (mudir) Darus Sunnah. Alhamdulilah sampai sekarang Ust Syamsul masih menjadi pimpinan di Darus Sunnah Malaysia. ${ }^{48}$

\section{b. Pengiriman Da'i ke-Mancanegara}

Adapun hal lain yang menunjung Ponpes Darus Sunnah sebagai ponpes yang bertarap internasional yakni, pengirimin da'i ke mancanegara, seperti Amerika, Malaysia, pengiriman da'i ke mancanegara dibiayai oleh dompet dhuafa'. Adapun ke daerah terpencil Indonesia seperti, Papua dan lainya dibiyayai oleh Ponpes Darus Sunnah. Pengiriman Da’i ke-Amerika sejak tahun 2017, hal tersebut terjadi disebabkan oleh seringnya KH Mustafa Ali Yaqub berangkat ke-Amerika baik delegasi dari Indonesia ataupun kepentingan pribadi, maka beliau suka menyempatkan diri bahkan menginap di pemukiman warga muslim Amerika, beliau enggan jika dipersilahkan menginap di hotel.

Berawal dari ke akraban beliau dengan masyarakat muslim Amerika, maka ada beberapa masjid di-Amerika yang membutuhkan ustadz untuk memberikan pemahaman agama yang sifatnya rabmatan lil a'alamin. Tidak hanya masjid, bahkan ada beberapa komunitas yang meminta ustadz untuk mengajarkan mereka agama Islam, misalnya mengajarkan baca al-Qur'an,

${ }^{47}$ Zia al-Haramain, (Direktur Darus-Sunnah) Wawancara oleh Asep Abdul Muhyi, Jakarta, 7 Agustus 2019.

${ }^{48}$ Zia al-Haramain, (Direktur Darus-Sunnah) Wawancara oleh Asep Abdul Muhyi, Jakarta, 7 Agustus 2019. 
memahami tafsir Qur'an, memhami Hadis dan berbagai pendapat ulama mengenai agama Islam, yang pastinya seorang ust yang dirikim oleh Darus Sunnah sudah mahir dalam bahasa Inggris dan Arab, sebagai bahasa pengantar dalam pembelajaran agama Islam. Namun setalah wafatnya KH Mustafa Ali Yaqub, program tersebut terhenti, dan sampai sekrang belum bisa ditindak lanjuti lagi.

c. Pertukaran Pelajar Ke-Mesir

Pengiriman maha santri ke Mesir, merupakan salah satu bukti bahwa Darus Sunnah merupakan pesantren bertarap internasional. Program pengiriman santri ke Mesir berkerjasama dengan Pesantren Lido. Pimpinan Pesantren Lido merupakan alumni Darus Sunnah dimana tiap tahun mengirimkan santrinya ke mesir sebanyak 30 orang, untuk tahun sekarang 5 orang berangkat ke-Mesir selama 1 bulan. Maha santri yang dikirim ke-Mesir tujuanya, untuk mengenal seluk beluk Negara Mesir dari mulai budaya, kultur, keagamaan, dan lainya. Program ini tiap tahun berjalan dan bekerjsama dengen Ponpes Darus Sunnah. ${ }^{49}$

Dengan beberapa program yang bekerjasama dengan beberapa organisasi dan universitas di berbagai mancan Negara, maka bisa dipastikan bahwasannya Ponpes Darus Sunnah merupakan pesantren hadis yang bertarap internasional. Kendati seperti itu kajian hadis di Ponpes darus Sunnah merupakan kajian hadis yang disesuaikan dengan kearipan lokal Nusantara. Bagaiman pengaplikasian hadis yang disesuaikan dengan budaya, adat istiadat setempat, khusunya di Nusantara. Maka hal tersebut menjadi salah satu misi Ponpes Darus Sunnah yang focus kajinya hadis.

Ponpes Darus Sunnah (Darus Sunnah Intrenational Institute for Hadist Sciences) merupakan salah satu pesantren yang fokus pada kajian hadis yang ada di Indonesia. Jika ditelaah bahwasanya masih sangat sedikit pesantren yang fokus kajianya pada hadis, dibandingkan dengan pesantren yang fokus pada al-Qur'an, fiqih, Bahasa, dan lainya. Cakupan Ponpes Darus Sunnah ini sudah bertarap Internasional (Darus Sunnah Intrenational Institute for Hadist Sciences).

Perkembangan Ponpes Darus Sunnah dari sejak berdirinya tahun 1997 sampai dengan sekarang 2019, terus mengalami perkembangan yang signifikan, baik dilihat dari jumlah santri, luas bangunan, dan alumni-alumni yang mumpuni di bidang hadis. Bahkan Ponpes Darus Sunnah berencana mengembangkan Darus Sunnah yang ada di Malaysia supaya lebih berkembang dan menjadi pusat kajian hadis di Malaysia.

d. Membuka Kelas Internasional

49 Zia al-Haramain, (Direktur Darus-Sunnah) Wawancara oleh Asep Abdul Muhyi, Jakarta, 7 Agustus 2019. 
Ponpes Darus Sunnah juga dalam waktu dekat akan menerima maha santri dari macan negara, khususnya mahasiswa yang kuliah disekitar Ponpes Darus Sunnah. Adapun sarana dan prasaran untuk menujang maha santri dari mancan negara dinilai sudah baik, seperti pengantar pembelajaran di Ponpes Darus Sunnah menggunakan Bahasa Inggris dan Bahasa Arab serta insfratuktur yang memadai. Hanya saja pengantar bahasa sehari-hari diluar jam pelajaran, maha santri Ponpes Darus Sunnah masih menggunakan bahasa Indonesia atau bahasa daerahnya masing-masing, hal tersebut bisa menyesuaikan, tutur dari Pimpinan Ponpes Darus Sunnah Ust H Zia Ul Haramain, Lc.

Pengajaran dengan menggunakan bahasa Arab dan bahasa Inggris didukung oleh para alumni Ponpes Darus Sunnah yang sudah mahir dan aktif berbahasa asing. Mayoritas pengajar di Po npes Darus Sunnah adalah alumni Ponpes Darus Sunnah itu sendiri, maka tidak heran jika pengantar dalam pembelajran menggunakan bahasa asing, namun terlepas dari hal itu, istilahnya pengabdian ( $\left.t a^{\prime} \mathbf{r}^{\prime}{ }^{\prime}\right)$ alumni maha santri kepada kiyainya. ${ }^{50}$

e. Prestasi Maha Santri di Tingkat Internasional

Sejak diresmikan pada 1997 Darus-Sunnah sudah melakukan wisuda sarjana sebanyak 15 kali. Tahun ini dilaksanakan wisuda ke-15 pada 19 Agustus 2017 Mahasantri Darus-Sunnah sudah meraih prestasi baik nasional maupun internasional sebagai berikut:

1) Salah seorang alumni Darus-Sunnah tahun 2005 Dwi Sukmanila Sayska melanjutkan studi magisternya di Universitas Kebangsaan Malaysia memperoleh penghargaan (Award) sebagai pelajar terbaik.

2) Tahun 2006, dua alumni terbaik Darus-Sunnah mendapat hadiah Haji dan Umrah dari atase Agama Kedutaan Besar Kerajaan Arab Saudi.

3) Mahasantri Darus Sunnah juga merupakan mahasiswa pada Perguruan Tinggi lain seperti UIN Syarif Hidayatullah, PTIQ dan IIQ. Tahun 2007 UIN Jakarta mengirimkan delapan lulusannya untuk melanjutkan S2 di Universitas al-Azhar Kairo, Mesir.

4) Pada 2010 empat mahasantri Darus Sunnah mengikuti lomba hafalan Hadis dan Ilmu Hadis Internasional yang diselenggarakan oleh Kedutaan Besar Arab Saudi bertempat di UIN Syahid, empat mahasantri DarusSunnah yang ikut mendapat juara semua. Juara pertama mendapat hadiah haji dan uang tunai USD 750 sementara tiga lainnya memperoleh hadiah USD 500 dan USD 250.

${ }^{50}$ Zia al-Haramain, (Direktur Darus-Sunnah) Wawancara oleh Asep Abdul Muhyi, Jakarta, 7 Agustus 2019. 
5) Dua mahasantri Darus Sunnah Saepul Anwar dan Muhammad al-Faiz Sa'di meraih kejuaraan beberapa kali. Yang pertama lomba debat dengan bahasa Arab se-Asean 2011, kedua Debat Ilmiah Kandungan al-Qur'an berbahasa Arab di UMI Makassar 2011, selanjutnya Debat Bahasa Arab antar Perguruan Tinggi se-Asean tahun 2013. Karena prestasi mereka tersebut mereka bertiga mendapat penghargaan Apresiasi Pendidikan Tinggi Islam kategori mahasiswa berprestasi oleh menteri Agama. ${ }^{51}$

6) Pada 2015 Mahasantri Darus-Sunnah Badrut Tamam meraih juara 2 hifzhil Qur'an 30 juz dalam pergelaran Musabaqah Tilawatil Qur'an tingkat Asia di Brunei Darussalam.

7) Pada 2015 dua mahasantri Darus-Sunnah kembali meraih juara pertama debat bahasa Arab tingkat Internasional yang dilaksanakan di University of Islamic Malaysia (UIM). ${ }^{52}$

\section{Kesimpulan}

Setelah mengkaji dan meneliti data-data yang relevan tentang metode, kurikulum dan berbagai sarana dan prasarana pesantren Darus Sunnah, diperoleh beberapa bukti yang menunjukkan kesimpulan sebagai berikut: Metode pendidikan di Darus Sunnah menggunakan empat metode, yaitu: mudzakarah, halaqah fajriyyah, munazhzhamah, dan istijam. Mudzakarah, yakni kegiatan yang dilaksanakan setelah shalat Isyak. Biasanya setiap berdiskusi mengenai mata pelajaran yang telah dan akan dipelajari. Halaqah Fajriyyah adalah kegiatan belajar yang dilakukan setelah shalat subuh. Di waktu ini, para dewan pengajar memberi penjelasan dan menambahkan pelajaran yang terkait dengan materi yang sudah dipelajari oleh maha santri sebelumnya. Adapun kurikulum yang diterapkan di Darus Sunnah meliputi Life Skill and Vocational Skill Multi Intellegences Active Learning (partisipatif, kolaboratif, sorogan) Habitual Curriculum (pembiasaan nilai-nilai) Integrated Curriculum (pendidikan terintegrasi)

Setelah meneliti data-data yang relevan tentang pesantren Darus Sunnah, diperoleh bukti-bukti yang menunjukkan bahwa Darus Sunnah adalah sebuah institusi pendidikan dan pengajaran hadis yang bertaraf internasioanl. Dengan beberapa program yang bekerjasama dengan beberapa organisasi dan universitas di berbagai manca Negara. Terdapat beberapa indicator yang menunjang institusi pendidikan dan pengajaran hadis yang bertaraf internasioanl diantaranya; Memiliki Cabang di Luar Negeri seperti di Malaysia, Pengiriman Da'i ke-Mancanegara seperti ke Amerika, Mesir, dan negara lainnya, melakukan pertukaran pelajar Ke-Mesir yang bekerjasama dengan Pesantren Lido untuk

${ }^{51}$ Darus Sunnah International Institute For Hadith Sciences, Buku Wisuda Sarjana Ke12 Tahun 2014 (Jakarta: Darus Sunnah International Institute For Hadith Sciences, 2014).

52 Darus Sunnah International Institute For Hadith Sciences, Buku Wisuda Sarjana Ke14 Tahun 2016 (Jakarta: Darus Sunnah International Institute For Hadith Sciences, 2016). 
selanjutnya dikirim ke-Mesir, membuka kelas internasional terutama untuk mahasiswa dari macan negara untuk belajar hadis di Darus Sunnah terutama untuk para mahasiswa dari mancan negara yang belajar hadis di Darus Sunnah dengan pengantar Bahasa Arab dan Bahasa Inggris, juga mendapatkan berbagai penghargaan dan kejuaraan bertarap internasional. Berdasarkan beberapa indikasi tersebut, bisa dipastikan bahwasanya pesantren Darus Sunnah merupakan pesantren hadis yang bertarap internasional.

\section{Bibliografi}

Abdullah, Abdullah, and Deden Mauli Darajat. "Peran Humas Pondok Modern Darusslam Gontor (PMDG) Dalam Membangun Lembaga Pendidikan." ETTIS AL: Journal of Communication 1, no. 2 (2016): 111-26. Ahmadi, Abu, and Joko Tri Prastya. Strategi Belajar Mengajar. Bandung: CV Pustaka Setia, 2005.

Akhiruddin, K M. "Lembaga Pendidikan Islam Di Nusantara." TARBIYA: Jurnal Ilmu Pendidikan Islam 1, no. 1 (2015): 195-219.

Arikunto, Suharsimi, and Cepi Safruddin Abdul Jabar. Evaluasi Program Pendidikan:Pedoman Teoretis Praktis Bagi Mahasiswa Dan Praktisi Pendidikan. Jakarta: Bumi Aksara, 2009.

Asrafi, Syamsudin. Metodologi Pembelajaran Bahasa Arab. Yogyakarta: Idea Press, 2010.

Aziz, Erwati. Darus-Sunnah International Institute for Hadith Sciences (Studi Tentang Kurikulum Dan Proses Pembelajaran). Yogyakarta: Pustaka Pelajar, 2019.

Cholidah, Ni'ma Diana. "Kontribusi Ali Mustafa Yaqub Terhadap Kajian Hadis Kontemporer Di Indonesia." Fakultas Ushuluddin UIN Syarif Hidayatullah Jakarta, 2011.

Dakir. Perencanaan Dan Pengembangan Kurikulum. Jakarta: PT. Rineka Cipta, 2004.

Darus Sunnah International Institute For Hadith Sciences. Buku Wisuda Sarjana Ke-12 Tahun 2014. Jakarta: Darus Sunnah International Institute For Hadith Sciences, 2014.

—. Buku Wisuda Sarjana Ke-14 Tabun 2016. Jakarta: Darus Sunnah International Institute For Hadith Sciences, 2016.

Deraman, Fauzi, and Faisal Ahmad Shah. "Pengajian Hadith Di Nusantara: Indonesia, Selatan Thailand, Singapura." Kuala Lumpur, n.d.

Dhofier, Zamakhsyari. Tradisi Pesantren Studi Tentang Pandangan Hidup Kyai. Jakarta: LP3ES, 1994.

Efendi, Riki. "Pemikiran Dan Aktifitas Dakwah Prof. Dr. KH. Ali Mustafa Yaqub, M.A.” Fakultas Dakwah UIN Syarif Hidayatullah Jakarta, 2009.

Fikri, Syah Ul-Haq Abdul. "Pemikiran Huku Islam Prof. Dr. KH. Ali Mustafa Yaqub, M.A." Fakultas Syariah dan Hukum, UIN Syarif Hidayatullah, 2016. 
382 | AL QUDS : Jurnal Studi Alquran dan Hadis vol. 4, no 2, 2020

Ginting, Abdurrahman. Esensi Praktis Belajar Dan Pembelajaran. Bandung: Humaniora, 2008.

Hamalik, Oemar. Dasar-Dasar Pengembangan Kurikulum. Bandung: PT Remaja Rosdakarya, 2007.

Kirkpatrick, Donald, L., and James D. Kirkpatrick. Evaluating Training Programs: The Four Levels. San Francisco: Berrett-Koehler Publishers, 2006.

Mahfudhon, U. N. Meniti Dakwah Di Jalan Sunnah. Biografi Kiai Ali Mustafa Yaqub. Jakarta: Yayasan Wakaf Darus-Sunnah, 2018.

Mahrus, Erwin, Zaenuddin Hudi Prasojo, and B Busro. "Messages of Religious Moderation Education in Sambas Islamic Manuscripts." Madania: Jurnal Kajian Keislaman 24, no. 1 (2020): 39-48.

Mubarok, Muhammad Husnul. "Pemikiran Ali Mustafa Yaqub Tentang Arah Kiblat.” UIN Sunan Kalijaga Yogyakarta, 2016.

Mudlofir, Ali. Aplikasi Pengembangan Kurikulum Tingkat Satuan Pendidikan Dan Bahan Ajar Dalam Pendidikan Agama Islam. Jakarta: PT Raja Grafindo Persada, 2012.

Muhibbin, Syah. Psikologi Pendidikan Dengan Pendekatan Baru. Bandung: Remaja Rosdakarya, 2007.

Nurdin, Nasrullah. "Prof. Dr. KH. Ali Mustafa Yaqub, MA. Muhaddis Nusantara Bertaraf Internasional." In 2ND INHAD International Muzakarah \& Mu'tamar on Hadith, 2017.

Rouf, Muhammad. "Memahami Tipologi Pesantren Dan Madrasah Sebagai Lembaga Pendidikan Islam Indonesia." TADARUS 5, no. 1 (2016): 6892.

Steenbrink, Karel. Pesantren, Madrasah, Sekolah: Pendidikan Islam Dalam Kurun Modern. Jakarta: LP3ES, 1994.

Tim Penyusun. Pedoman Akademik Madrasab Darus Sunnah Eanam Tabun Setingkat Tsanawiyah Aliyah, 2014-2020. Jakarta: Darus Sunnah, 2014.

Wafa', Ali. "Kiai Ali Mustafa Yaqub: Penggagas Kajian Hadis Di Indonesia.” In 2nd Inhad International Murakarah \& Mu'tamar On Hadith, 2017.

Yaqub, Ali Mustafa, and Nurul Huda Maarif. Haji Pengabdi Setan. Jakarta: Pustaka Firdaus, 2006.

Zarkasyi, Abdullah Syukri. Langkah Pengembangan Pesantren Dalam Rekontruksi Pendidikan Dan Tradisi Pesantren Religiusitas Iptek. Yogyakarta: Pustaka Pelajar, 1998.

Zarkasyi, Hamid Fahmy. "Imam Zarkasyi's Modernization of Pesantren in Indonesia (A Case Study of Darussalam Gontor)." QIJIS (Qudus International Journal of Islamic Studies) 8, no. 1 (2020): 161-200. 